\title{
Spline Function Expression by Orthogonal Polynomial Weighted Sampling for High-Speed Electric Field Calculation
}

\author{
Yohei Miyazaki Student Member (Hokkaido Institute of Technology) \\ Kazutaka Kitamori Member (Hokkaido Institute of Technology)
}

\begin{abstract}
Keywords : Monte Carlo simulation, B-spline function, orthogonal polynomial weighted sampling, electric field calculation, high speed calculation
\end{abstract}

In the simulation of plasma processes, minimizing the error associated with the electric field calculation in the vicinity of the sheath is an important consideration. The sheath length scale when compared to the plasma size and the fact that the electric fields must be solved for self-consistently with equations describing the plasma chemistry make the electric field solution particularly expensive. Because an internal electric field is calculated based on the density of charged particles, it is necessary to obtain the density of charged particles correctly but at minimum possible expense. We describe an electric field simulation with high speed and good accuracy enabled by the description of the density of charges by spline functions. Preciously, we have taken advantage of the orthogonality of the Legendre polynomial in our methodology described as LPWS (Legendre Polynomial Weighted Sampling). Sampling with other orthogonal functions is also possible and we have generalized our method with this in mind. The generalization, Orthogonal Polynomial Weighted Sampling (OPWS), the determination of coefficient of the B-spline function from the orthogonal expansion coefficients has been developed and is described in this paper.

The electric field calculation method using the spline function is now described. The charge density $\rho$ is related to the B-spline basis function $M$ of order $m$.

$$
\rho(x, y, z)=\sum_{i=1}^{n_{x}} \sum_{j=1}^{n_{y}} \sum_{k=1}^{n_{z}} c_{i j k} M_{m i}(x) M_{m j}(y) M_{m k}(z)
$$

The interelectrode potential is a function of charged particle densities grouped as $M_{m i} M_{m j} M_{m k}$ corresponding to the charged particles group in a limited segment.

$$
\nabla^{2} V_{i j k}(x, y, z)=-\frac{M_{m i}(x) M_{m j}(y) M_{m k}(z)}{\varepsilon_{0}}
$$

The entire internal potential $V(x, y, z)$ is the sum of $V_{i j k}(x, y, z)$ over the entire space.

$$
V(x, y, z)=\sum_{i=1}^{n_{x}} \sum_{j=1}^{n_{y}} \sum_{k=1}^{n_{z}} c_{i j k} V_{i j k}(x, y, z)
$$

Figure 1 includes the charge density represented by B-Spline basis functions when assuming $c_{i}=1$ in a by the one dimension model. The electric field calculated from B-spline basis function in Fig. 1 is presented in Fig.2. The B-spline basis function is assumed to be coefficient $c_{i}=1$, the Poisson equation was calculated beforehand, and electric field corresponding to solving each B-Spline basis function was calculated. The electric field corresponding to an actual density of charged particles is obtained by inserting the coefficient $c_{i}$ obtained from LPWS.

The calculation time for the case of a one dimension electric

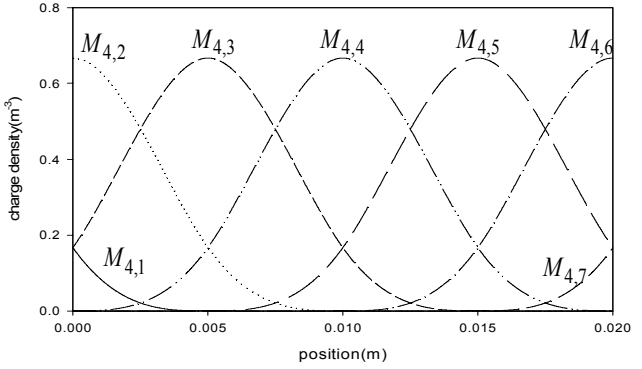

Fig. 1. charge density by B-spline when assuming $c_{i}=1$ in a one dimension model

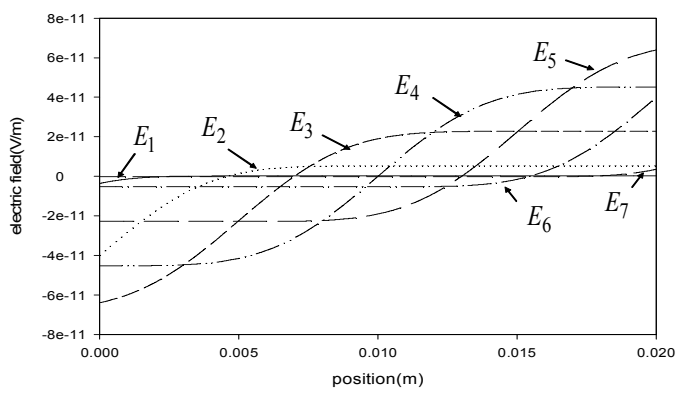

Fig. 2. Electric field calculated from the B-Spline in Fig.1

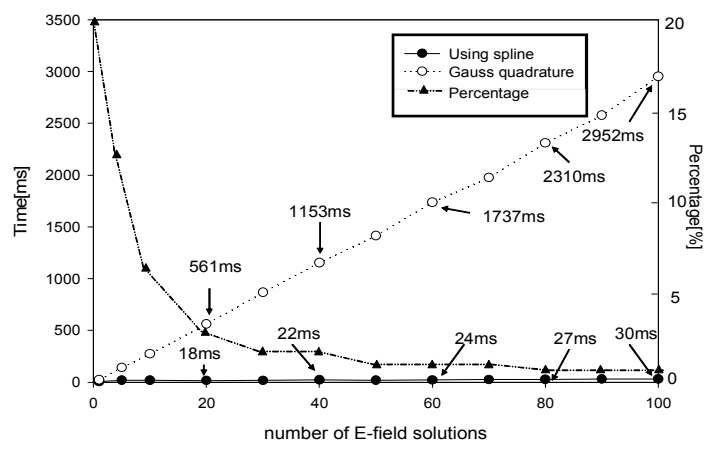

Fig. 3. Calculation time for electric field

field is calculated by Gauss quadrature and using the Spline method is presented in Fig. 3. The electric field calculation method that used the spline function was high-speed, and it has been shown to be efficient especially for high calculation frequencies. 


\title{
高速電界計算のための直交展開サンプリングによる スプライン関数表現
}

\author{
学生員 宮崎 洋平* 正 員 北守 一隆* \\ Spline Function Expression by Orthogonal Polynomial Weighted Sampling \\ for High-Speed Electric Field Calculation \\ Yohei Miyazaki*, Student Member, Kazutaka Kitamori*, Member
}

\begin{abstract}
In the simulation of plasma processes, minimizing the error associated with the electric field calculation in the vicinity of the sheath is an important consideration. The sheath length scale when compared to the plasma size and fact that the electric fields must be solved for self-consistently with equations describing the plasma chemistry make the electric field solution particularly expensive. Because an internal electric field is calculated based on the density of charged particles, it is necessary to obtain the density of charged particles correctly but at minimum possible expense. We describe an electric field simulation with high speed and good accuracy enabled by the description of the density of charges by spline functions. Preciously, we have taken advantage of the orthogonality of the Legendre polynomial in our methodology described as LPWS (Legendre Polynomial Weighted Sampling). Sampling with other orthogonal functions is also possible and as such we have generalized our method. The generalization, Orthogonal Polynomial Weighted Sampling (OPWS), whereby the method of obtaining the coefficient of B-spline function from the coefficient of the orthogonal expansion has been developed and is described in this paper.
\end{abstract}

キーワード : モンテカルロシミュレーション, B-スプライン基底関数, 直交展開サンプリング, 電界計算, 高速計算

Keywords : Monte Carlo simulation, B-spline function, orthogonal polynomial weighted sampling, electric field calculation, high speed calculation

\section{1. はじめに}

プラズマプロセスは弱電離プラズマを利用した半導体加 工技術としてすでに知られ，プラズマ利用技術として近年 ではカーボンナノチューブ配向成長 ${ }^{(1)} に$ 用いられるプラズ マ CVD や, 細管内面への薄膜のスパッタコーティングにマ イクロプラズマ(2)が利用されており, プラズマ特性と構造解 析が実験, シミュレーションの両面から進められている。

Horie ら ${ }^{(3)}$ はプラズマプロセスシミュレーションとして RF 平行平板プラズマを対象に物理的境界条件の取り扱いに優 れた Monte Carlo simulation（以降 MCS と記す）に LPWS (Legendre Polynomial Weighted Sampling) $)^{(4)}$ を用い計算時間の 高速化を図っている。このシミュレーションから得られた 知見として精緻な境界条件の適用により, 両極の高電界の シース部を通過する電子に与える電離に寄与するエネルギ 一量の計算が不安定の要因となると予見されており, 安定 な計算のためには電界一定とするタイムステップ $(\Delta t)$ を

* 北海道工業大学

T006-8585 札幌市手稲区前田 7 条 15 丁目 4-1

Hokkaido Institute of Technology

4-1, 7-15, Teine-ku, Sapporo 006-8585
さらに分割し短くする必要があり, 計算コストを増加させ る。Satoh (5) $^{(5)}$ LPWS に対し 2 次元および 3 次元への拡張 を行いサンプリング可能なことを示した。2,3 次元において も電界計算を行う場合は 1 次元に対し 2 乗 3 乗もの計算コ スト増加が予想される。Kozaki ら ${ }^{(6)}$ は LPWS を PIC/MC simulator に組み込み, 荷電粒子密度をサンプルすることで 内部電荷による電界計算の精度が向上することを確認して いる。これらの論文で用いられている LPWS は，区間分割 して得られた分布を B-スプライン基底関数を信頼度として 用い滑らかに接続している。分割せず一区間とすると分布 全体は急な立ち上がりや凹凸を含むものとなることからル ジャンドル展開の高次の項まで必要となる。高次の項は統 計変動の影響を受けやすいため分割することで単純な曲線 部を選び高次の項がすみやかに 0 となるような区間として いる。本論文では LPWS を一般化した直交展開サンプリン グについて精度を評価するとともに, 精度の点で理論的根 拠の明らかにされていない滑らかな接続とするのではな く, 区間ごとの直交展開サンプリングから得られた展開係 数の情報をもとにスプライン関数表現し密度関数の精度を 上げる一方，これらにより表現されたスプライン関数の特 
性とポアソン方程式の線形性を生かした高速電界計算法を 提案する。

\section{2. 直交展開サンプリング}

$\langle 2 \cdot 1\rangle$ 直交展開サンプリング＼cjkstart筆者らは対象となる 分布を直交多項式により展開した形で表すことができるサ ンプリング方法を直交展開サンプリングとして提案してい る ${ }^{(7)}$ 。英語表記は Ventzek らの LPWS と語の対応を考え Orthogonal Polynomial Weighted Sampling とした。LPWS はル ジャンドル多項式を利用した直交展開サンプリングであ る。区間 $[a, b]$ において定義される $n$ 次の多項式 $p_{n}(x)$ にお いて次式が成り立つとき $p_{n}(x)$ は $[a, b]$ で重み $r(x)$ に関して 直交多項式系をなす。

$$
\int_{a}^{b} r(x) p_{m}(x) p_{n}(x) d x=0 \quad(m \neq n)
$$

ここでは，直交多項式補間などで知られるチェビシェフ多 項式（第一種特殊）を用いた直交展開サンプリングの方法 を示す。

密度関数 $f(x)$ が区間 $[\alpha, \beta]$ で与えられたとき, チェビシェ フ多項式 $T_{q}(X)$ により次式に展開される。

$$
\begin{aligned}
& f(X)=\frac{1}{2} A_{0} T_{0}(X)+A_{1} T_{1}(X)+A_{2} T_{2}(X)+\cdots \\
& X=\frac{2\{x-(\beta+\alpha) / 2\}}{\beta-\alpha}
\end{aligned}
$$

ここで $q$ は多項式の次数である。係数 $A_{c_{q}}$ はチェビシェフ 多項式 $T_{q}(X)$ の直交性から次式により得られる。

$$
A_{C_{q}}=\frac{2}{\pi} \int_{-1}^{1} \frac{f(X) T_{q}(X)}{\sqrt{1-X^{2}}} d X
$$

Wajima の数学的証明 ${ }^{(8)}$ により (5)式が成り立ち,

$$
\frac{2}{\pi} \int_{-1}^{1} \frac{f(X) T_{q}(X)}{\sqrt{1-X^{2}}} d X=\lim _{n \rightarrow \infty} \frac{2}{\pi} \frac{1}{n} \sum_{s=1}^{n} \frac{T_{q}\left(X_{s}\right)}{\sqrt{1-X_{s}^{2}}}
$$

右辺を有限和で打ち切ることでチェビシェフ多項式による 重み付サンプリング (Chebychev Polynomial Weighted Sampling:CPWS $)^{(7)}$ として次式を得る。

$$
A_{C P W S}=\frac{2}{\pi} \cdot \frac{1}{n} \sum_{s=1}^{n} \frac{T_{q}\left(X_{s}\right)}{\sqrt{1-X_{s}^{2}}}
$$

ここで $X_{s}$ はサンプル值 $x_{s}$ を区間 $[-1,1]$ に対応するよう ( 3 )式により変換したサンプル值， $n$ はサンプル数である。 チェビシェフ多項式 $T_{q}(X)$ と直交多項式系を為すための重み 関数 $1 / \sqrt{1-X_{s}^{2}}$ との積をサンプルの重みとし, 重み付サンプ リングの総和から( 6 )式により密度関数のチェビシェフ展 開時の係数 $A_{C P W S q}$ を得る。

$\langle 2 \cdot 2\rangle$ 直交展開サンプリングの評価＼cjkstart直交展開サン プリング時に用いる直交多項式系について LPWS と CPWS それぞれの結果を調べた。既知の関数( 7$),(8)$ 式に従った乱 数を発生させサンプリングした結果について述べる。

$$
f(x)=\frac{1}{2} x^{3}+\frac{1}{2}
$$

$$
f(x)=e^{x}
$$

Fig.1に( 8$)$ 式に従う区間 $[0,6]$ の乱数 1000 個に LPWS, CPWS を行った結果を示す。理論值である( 8 )式と若干の差 が確認される一方, LPWS と CPWS の結果はほぼ重なって いる。Table 1 に( 7 )式に従う区間 $[-1,1]$ の乱数に 3 次の項 まで考慮した LPWS, CPWS を乱数の個数 1000, 10000, 100000，1000000のときに対して行い, 理論值との誤差を示 す。誤差は乱数を発生させた区間を 100 等分した点における 理論值 $f_{l}(x)$, サンプリング結果 $f_{l}^{\prime}(x)$ とし次式により計算した。

$$
\operatorname{error}[\%]=\sum_{l=1}^{100} \frac{\left|f(x)_{l}-f_{l}^{\prime}(x)\right|}{f_{l}(x)} \ldots
$$

サンプリングされる乱数列の差異によりサンプリング結果 にバラツキが生じるため指定の個数についてサンプリング した誤差を計算し，10 回繰り返したときの誤差の平均值を 結果として記載した。3 次関数であるため乱数 1000 個程度 でも大きな誤差は無い。また乱数 10000 個を超えると LPWS, CPWS 共に誤差 $2 \%$ 程度となり, 高い精度でサンプ リングを可能としている。またサンプリング数の増大に伴 って, LPWS の方が若干だが CPWS より精度が良くなる。 Table 2 は, (8)式に従う区間 [0,6] の乱数を 10 次の項まで 考慮した LPWS, CPWS を行い, 誤差を示した。乱数 1000 個では, LPWS 及びCPWS も $10 \%$ 以上の誤差がある。LPWS， CPWS 共に乱数 1000000 個以上では，かなり誤差が小さく なる。( 7 )式の分布に対する検証と同様に若干ではあるが LPWS のほうが誤差の小さい傾向がある。LPWS と CPWS

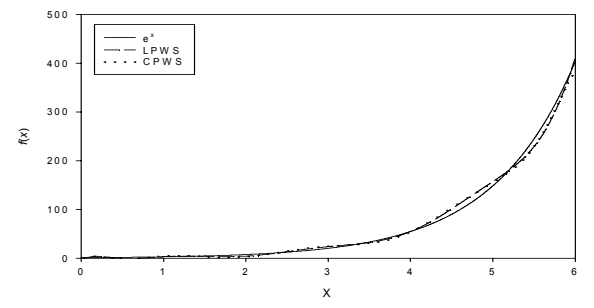

Fig. 1. LPWS and CPWS from Eq.( 8 ).

Table 1. Error by LPWS and CPWS from Eq.( 7 ).

\begin{tabular}{|r|r|r|}
\hline No. of pcs & \multicolumn{1}{|c|}{ LPWS } & \multicolumn{1}{c|}{ CPWS } \\
\hline \hline 1000 & $6.15 \%$ & $6.52 \%$ \\
\hline 10000 & $2.07 \%$ & $2.06 \%$ \\
\hline 100000 & $0.55 \%$ & $0.78 \%$ \\
\hline 1000000 & $0.18 \%$ & $0.64 \%$ \\
\hline 10000000 & $0.05 \%$ & $0.63 \%$ \\
\hline
\end{tabular}

Table 2. Error by LPWS and CPWS from Eq.( 8 ).

\begin{tabular}{|r|r|r|}
\hline No. of pcs & \multicolumn{1}{|c|}{ LPWS } & \multicolumn{1}{c|}{ CPWS } \\
\hline \hline 1000 & $15.61 \%$ & $21.16 \%$ \\
\hline 10000 & $4.28 \%$ & $7.14 \%$ \\
\hline 100000 & $1.74 \%$ & $3.55 \%$ \\
\hline 1000000 & $0.63 \%$ & $1.34 \%$ \\
\hline 10000000 & $0.13 \%$ & $0.30 \%$ \\
\hline
\end{tabular}


に大きな差異は認められなかったが，若干 LPWS の精度が 良いことから本論文では以降は直交展開サンプリングとし てLPWS を用いる。

〈2·3〉 LPWS によるスプライン関数表現ＬPWS で は，サンプリング対象とする範囲を少ない区間数で区切り， 区間内の密度分布をルジャンドル展開し，B-スプライン基 底関数を信頼度とした接続を行っている。Fig.2 に示すよう に区間 $\tau_{v-2} \sim \tau_{v+1}$ を一つの区間とみなし, LPWSにより得られ る分布関数を $f_{A}(\tau)\left[\tau_{v-2}, \tau_{v+1}\right]$ とし，同様に区間をずらして $f_{B}(\tau)$ 区間 $\left[\tau_{v-1}, \tau_{v+2}\right], f_{C}(\tau)$ 区間 $\left[\tau_{v}, \tau_{v+3}\right]$ とすると， 3 階の Bスプライン基底関数 $M_{A}, M_{B}, M_{C}$ を $f_{A}, f_{B}, f_{C}$ それぞれに対応 する信頼度として次式

$$
f(\tau)=f_{A}(\tau) M_{A}(\tau)+f_{B}(\tau) M_{B}(\tau)+f_{C}(\tau) M_{C}(\tau)
$$

により各区間を滑らかに繋ぎ合わせる手法を用いていた ${ }^{(4)}$ 。 ここで $M_{A}$ の非零区間は $M_{A}>0\left(\tau_{v-2}<\tau<\tau_{v+1}\right)$ とし $M_{B}, M_{C}$ は それぞれ一区間ずらしたものとなる。1 次以上の B-スプラ イン基底関数を用いることで，微分しても連続性を保つこ とが可能である。LPWS において急な立ち上がりや凹凸を多 く含む分布に対してサンプリングを行うと, 高次の項によ る統計変動が現れる。その解決策として，サンプル数によ る統計変動を受けない程度の大きな幅で区間分割し，区間 内を低次項で近似できるようにして，サンプル区間をオー バーラップさせ各区間で得られた分布を繋ぎ合わせてい た。B-スプライン基底関数を信頼度とすると, 各区間では 中央を最も信頼することになるが，サンプリングにより関 数として得られた分布と, 実際の分布の一致する程度が Bスプライン基底関数による信頼度と等価ではない。

本論文では，サンプリング時に統計変動を受けにくい

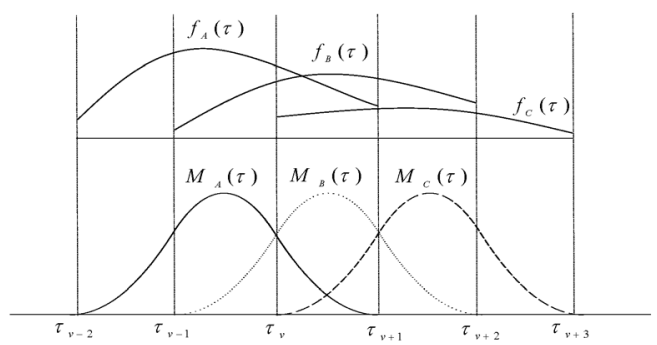

Fig. 2. Overlapping LPWS distribution functions with support functions B-spline basis function ${ }^{(4)}$.

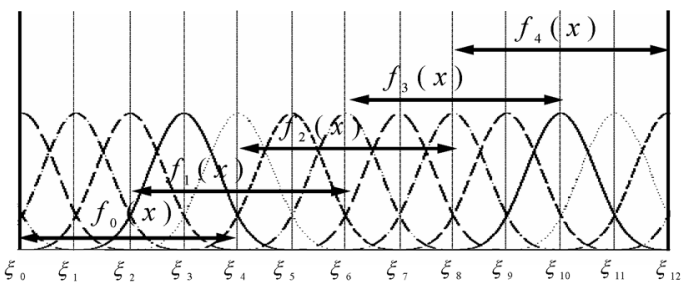

Fig. 3. Method of dividing the section and B-spline basis function corresponding to Sampling.
LPWS の低次項の係数をもとに，与えられた各 B-スプライ ン基底関数に対する係数を求めることで, 分布関数をスプ ライン関数表現する方法を示す。

1 次元モデルとして対象となる区閒を Fig.3 に示すよう 12 分割し, 区間 $\left[\xi_{2 w}, \xi_{2 w+4}\right]$ における分布関数 $f_{w}(x)$ $(w=0,1,2,3,4)$ にLPWS を行い全体の分布関数 $f(x)$ 区間 $\left[\xi_{0}, \xi_{12}\right]$ をスプライン関数表現する方法を述べる。分布関数 $f_{w}(x)$ を 2 次までのルジャンドル多項式 $P_{q}(X)$, LPWS から得られる係 数 $A L P W S_{w, q}$ により展開し次式となる。

$$
\begin{aligned}
& f_{w}(\chi)=A_{L P W S_{w, 0}} P_{0}(\chi)+A_{L P W S_{w, 1}} P_{1}(\chi)+A_{L P W S_{w, 2}} P_{2}(\chi) \\
& (w=0,1,2,3,4) \\
& \chi=\frac{2\left\{x-\left(\xi_{2 w+4}+\xi_{2 w}\right) / 2\right\}}{\xi_{2 w+4}-\xi_{2 w}}
\end{aligned}
$$

ここで $q$ は多項式の次数である。また分布関数 $f(x)$, 区間 $\left[\xi_{0}, \xi_{12}\right]$ は 4 階の B-スプライン基底関数 $M_{4, i}$, 非零区間 $M_{4, i}>$ $0\left(\xi_{i-4}<x<\xi_{i}\right)$, 係数 $c_{\mathrm{i}}, i=1,2 \cdots, n_{x}, n_{x}$ は B-スプライン基底関 数の個数とし次式で表されるとき,

$$
f(x)=\sum_{i=1}^{n_{x}} c_{i} M_{4, i}(x)
$$

$f_{\mathrm{w}}(\chi)$ は次式となり,

$$
f_{w}(\chi)=\sum_{i=2 w+1}^{2 w+7} c_{i} M_{4, i}(\chi)
$$

ルジャンドル展開時の係数 $A_{L q}$ は, 区間 $[\alpha, \beta]$ において次式 により得られるので,

$$
A_{L_{q}}=\frac{2 q+1}{2} \int_{-1}^{1} f(X) P_{q}(X) d x
$$

$f_{w}(\chi)$ 展開時の係数 $A_{L_{w, q}}$ は(14)式を代入し次式となる。

$$
A_{L_{w, q}}=\frac{2 q+1}{2} \int_{-1}^{1} P_{q}(\chi) \sum_{i=2 w+1}^{2 w+7} c_{i} M_{4, i}(\chi) d x
$$

(16)式を各 B-スプライン基底関数を積分した形に分け $m_{w, q, i}$ とし次式となる。

$$
m_{w, q, i}=\frac{2 q+1}{2} \int_{-1}^{1} P_{q}(\chi) M_{4, i}(\chi) d x
$$

よって(16)式は次式に示すように書くことができ，

$$
A_{L_{w, q}}=\sum_{i=2 w+1}^{2 w+7} c_{i} m_{w, q, i}
$$

ここで $w=0$ のときは，以下のようになる。

$$
\left.\begin{array}{l}
A_{L_{0,0}}=c_{1} m_{0,0,1}+c_{2} m_{0,0,2}+\cdots+c_{6} m_{0,0,6}+c_{7} m_{0,0,7} \\
A L_{0,1}=c_{1} m_{0,1,1}+c_{2} m_{0,1,2}+\cdots+c_{6} m_{0,1,6}+c_{7} m_{0,1,7} \\
A_{L_{0,2}}=c_{1} m_{0,2,1}+c_{2} m_{0,2,2}+\cdots+c_{6} m_{0,2,6}+c_{7} m_{0,2,7}
\end{array}\right\}
$$

$w=1,2,3,4$ の場合も同じ形式で示すことができ, それらを (20)式に示すように行列に配置する。(20)式の右辺をLPWS により得られる $A_{L P W S_{W, q}}$ で置き換えこの行列を解くことによ り, B-スプライン関数の係数 $c_{i}$ を推定する。1 次元モデルの 制約条件として LPWS の対象となる分布関数の数 $w+1$, 多 項式の次数 $q, \mathrm{~B}$-スプライン基底関数の個数 $n_{x}$ より, 


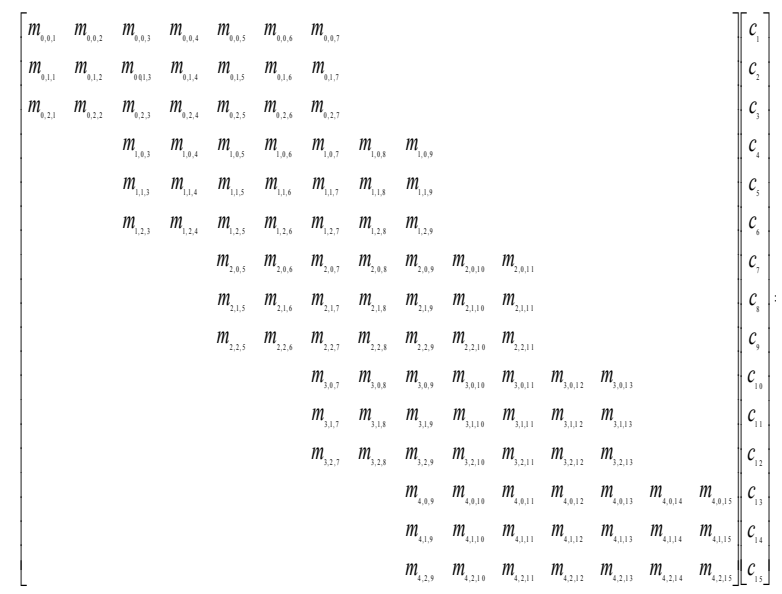

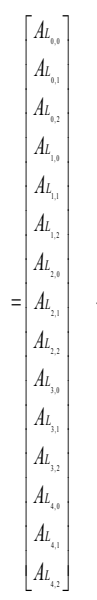

$(q+1)(w+1)=n_{x}$

を満たす必要がある。

従来は区間ごとに LPWS より得られた分布を接線連続と した分布関数となるよう B-スプライン基底関数を用いて滑 らかに繋ぎ合わせていた。また, 分布が複雑になる場合には, 高次項まで考慮したサンプリングを行うか, 区間分割数を多 くする必要があった。前者は高次項の収束に, 後者は数によ る統計変動を減ずるためにサンプル個数を増やす必要があ る。本手法では，区間分割数が少なく低次項を考慮した LPWS からスプライン関数表現をすることで, 区間内のマク ロパラメータを満たすサンプリング結果を得ることが可能 となると同時に，より数学的な意味が明確になった。

\section{3. スプライン関数を用いた高速電界計算}

プラズマプロセス MCS では非常に短い時間, 電界一定と して荷電粒子の運動を計算しているが，シース部において は強い電界が急激に変化するため, 電界一定とする時間が 長いと荷電粒子に余分なエネルギーが与えられシミュレー ションを不安定にする要因となっている。安定な計算のた めには計算ステップ $(\Delta t)$ をさらに分割し短くする必要があ り, 計算コストを増加させる。2 次元， 3 次元の電界計算は 2 乗, 3 乗の計算コスト増加が予想され，シミュレーション を効率よく行うためには, 高速な電界計算が有効であると 考えられる。ここでは, スプライン関数の特性とポアソン
方程式の線形性を生かしスプライン関数により与えられる 荷電粒子密度から高速に電界を計算する方法について述べ る。

電界は，外部電界と内部電界の和で与えられる。外部電 界はラプラス方程式で計算され， $1 \mathrm{~V}$ 時の電界から各点にお ける比例計算により電界が求められる。内部電界はポテン シャル $V$, 電荷密度 $\rho$, 真空の誘電率 $\varepsilon_{0}$, 有界開集合 $\Omega$ とし, ポアソン方程式及び境界条件

$$
\left.\begin{array}{ll}
\nabla^{2} V=\frac{\partial^{2} V}{\partial^{2} x}+\frac{\partial^{2} V}{\partial^{2} y}+\frac{\partial^{2} V}{\partial^{2} z}=-\frac{\rho}{\varepsilon_{0}} & \text { in } \Omega \\
V=0 & \text { on } \partial \Omega
\end{array}\right\}
$$

から, 次式により各 $x, y, z$ 方向の電界 $E_{x}, E_{y}, E_{z}$ が得られる。

$$
E_{x}=-\frac{\partial V}{\partial x}, E_{y}=-\frac{\partial V}{\partial y}, E_{z}=-\frac{\partial V}{\partial z}
$$

電荷密度は $m$ 階の B-スプライン基底関数の積と係数 $c_{i, j, k}$ に より表現すると次式となり，

$$
\rho(x, y, z)=\sum_{i=1}^{n_{x}} \sum_{j=1}^{n_{y}} \sum_{k=1}^{n_{z}} c_{i, j, k} M_{m, i}(x) M_{m, j}(y) M_{m, k}(z)
$$

$M_{m, i}(x) M_{m, j}(y) M_{m, k}(z)$ は荷電粒子群の密度に相当し, それらを 合計したものが全体の荷電粒子密度となる。ここで $n_{x}, n_{y}, n_{z}$ はそれぞれ $x, y, z$ 方向の $\mathrm{B}$-スプライン基底関数の個数であ る。荷電粒子群 $M_{m, i}(x) M_{m, j}(y) M_{m, k}(z)$ に対応するポテンシャル $V_{i, j, k}(x, y, z)$ は $(23)$ 式に示された電荷密度から, 次式となり

$$
\nabla^{2} V_{i, j, k}(x, y, z)=-\frac{M_{m, i}(x) M_{m, j}(y) M_{m, k}(z)}{\varepsilon_{0}} \ldots
$$

それらの解 $V_{i, j, k}(x, y, z)$ を重社合わせることで, 次式のように 全体のポテンシャル $V(x, y, z)$ が得られる。

$$
V(x, y, z)=\sum_{i=1}^{n_{x}} \sum_{j=1}^{n_{y}} \sum_{k=1}^{n_{z}} c_{i, j, k} V_{i, j, k}(x, y, z)
$$

B-スプライン基底関数の係数 $c_{i, j, k}$ は偏微分には影響の無い 定数であるため（静止時, 時間により荷電粒子密度が変化 するので実際は時間 $t$ の関数となる), あらかじめ各 B-スプ ライン基底関数に対応する電界を計算可能である。荷電粒 子密度から係数 $c_{i, j, k}$ が得られたら, 計算済みの基準となる各 荷電粒子群に対応するポテンシャルに係数 $c_{i, j, k}$ を乗じ, それ ら重ね合わせることでポテンシャルが計算される。電荷重 畳法においては, 内部電荷を複数の内部仮想電荷として配 置し, それらによるポテンシャルを重㸚合わせて計算を行 う。また電界の変化をパラメータとしてあらかじめメモリ に置き参照することで計算コストを掛けない方法がある。 本論文で提案する方法は, 各 B-スプライン基底関数に対応 する電界をあらかじめ計算しておくことで, 同じ境界条件 を持ち電荷密度が変化する空間で繰り返し電界計算を行う 際の計算コストを大幅に減らすことができる。(10)式におい ても B-スプライン基底関数を用いる方法と同様にあらかじ めルジャンドル多項式と B-スプライン基底関数との積を適 切な区間で定義し, あらかじめ電界を計算することは可能 
であるが，複雑な分布を対象としたときに高次項まで扱う 必要があり, 電界の重ね合わせ時に計算時間が増加するた め, 分布を B-スプライン関数表現する本手法がより高速で ある。計算精度の高い電界計算法では一般に計算コストが 大きくなるが，本手法においては一度，基準となる荷電粒 子密度から電界を計算するときに高精度な電界計算法を用 いることで高精度電界計算を可能とする。次回からは荷電 粒子密度に対し LPWS を行いB-スプライン基底関数の係数 を得ることで，正確な電界が高速に求められる。このよう にスプライン関数を用いた計算手法は，精度と速度を両立 することを可能としており，プラズマプロセス MCS のよう な, 同じ装置内で内部電荷密度が変化し繰り返し電界計算 を必要とする場合に，特に有効である。B-スプライン基底 関数の積により 2 次元, 3 次元での電荷密度を表すことで, 境界形状が曲線を含まない 2 次元, 3 次元での高速電界計算 が可能となる。

ここで 1 次元空間モデルの例を示す。計算領域は $\mathrm{x}=0$ 〜 $0.02 \mathrm{~m}$ とする。電荷密度 $\rho$ を 1 次元 4 階の B-スプライン基 底関数 $M_{4, i}\left(i=1,2, \cdots, n_{x}\right)$ を用い, 次式となる。

$$
\rho(x)=\sum_{i=1}^{n_{x}} c_{i} M_{4, i}(x)
$$

ここで非零区間 $M_{4, i}>0$ は, $0.005(i-4)<x<0.005 i$ である。Fig.4 に $n_{x}=7$ とし係数 $c_{i}$ を除いた $\left(c_{i}=1\right.$ と同じ $)$ 各 B-スプライン による荷電粒子密度を示した。1 次元のポアソン方程式を解 くと次式が得られ，

$$
E(x)=-\frac{1}{\varepsilon_{0}} \int_{x}^{d} \rho(x) d x+\frac{1}{\varepsilon_{0} d} \int_{0}^{d} x \rho(x) d x
$$

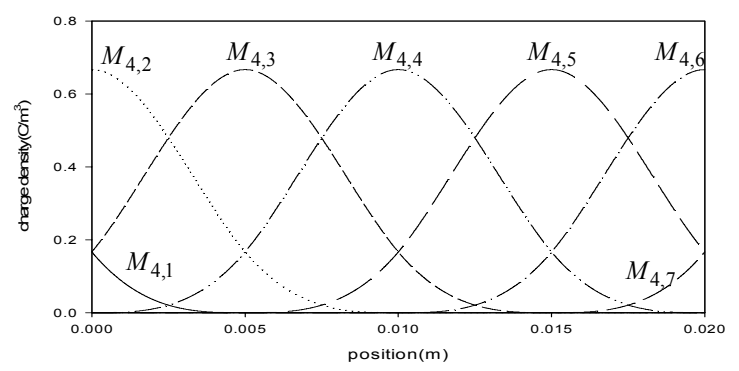

Fig. 4. Charge density by B-Spline basis function when assuming $c_{i}=1$ by the one dimension model.

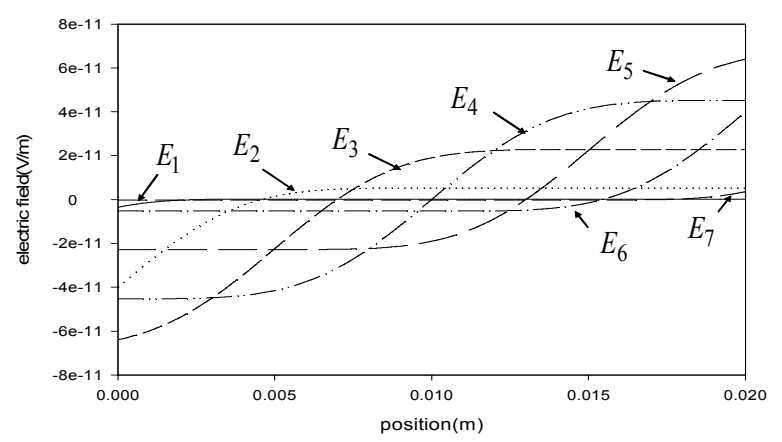

Fig. 5. Electric field calculated from B-Spline basis function that Fig.4 shows.
B-スプライン基底関数 $M_{4, i}$ は局所の荷電粒子群と対応し, そ の荷電粒子群それぞれに対する電界は, 次式となる。

$$
E_{i}(x)=-\frac{1}{\varepsilon_{0}} \int_{x}^{d} c_{i} M_{4, i}(x) d x+\frac{1}{\varepsilon_{0} d} \int_{0}^{d} x c_{i} M_{4, i}(x) d x
$$

Fig.5 に(29)式から計算された $c_{i}$ を除いた荷電粒子群に対 する電界を示す。得られた各電界が基本值となり, 実際の 全体の内部電界は, 次式に示すよう各電界に係数 $c_{i}$ を乗じ 重ね合わせたものとなる。

$$
E(x)=\sum_{i=1}^{n} c_{i} E_{i}(x)
$$

\section{4. サンプリングと電界計算の評価}

LPWS による分布のスプライン関数表現と, スプライン関 数を用いた電界計算の結果を確認すると共に計算時間を示

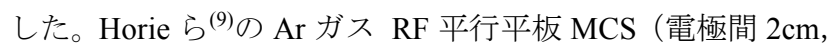
電源 270V）の結果を元にプラズマが定常状態時における電 子・イオンを生成する MCS を行い電子とイオンそれぞれを サンプリングした。サンプリングは $\langle 2 \cdot 3\rangle$ 節で述べた 1 次 元モデルと同様のサンプリングを行う。電界計算に用いる B-スプライン基底関数に対応する電界 $E_{i}$ はサンプリングに 用いる B-スプライン基底関数と同数の 15 となる。

Fig.6 に定常状態かつ外部電界 0 である時の電子とイオン の密度をサンプリングしたものを示す。Fig.7 はサンプリン グにより B-スプライン基底関数の係数を得て, スプライン 関数による電界計算に適用し得られた電界である。Horie ら の示す結果と一致しておりサンプリングと電界計算が正し く行われたことが確認された。

1 次元における平行平板間の内部電界は(30)式により求め ることができるが，シミュレーションにおいては数值積分 を用いるのが一般的と考えられる。ここでは, ガウス求積 法とスプライン関数を用いた電界計算により繰り返し電界 を計算した時の計算時間と比率を Fig. 8 に示す。縦軸右側に 示す比率は各繰り返し回数時におけるガウス求積法の計算 時間を $100 \%$ としたときの高速電界計算法の比率である。使 用した計算機は PentiumM1.6MHz, Memory768Mbyte, OS は WindowsXP Professional プログラムコードは Java で記述 した。ガウス求積法は Visual Numerics 社の JMSL1.0を用い 適応型の 31 点ガウスークロンロッド積分を行った。電界計

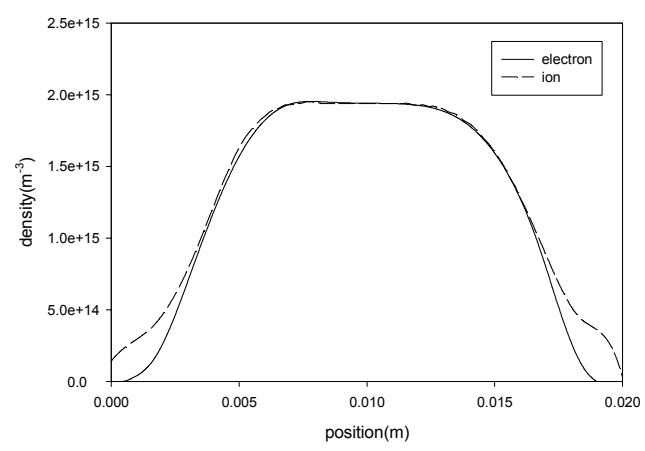

Fig. 6. Spatial variations of electron and ion. 


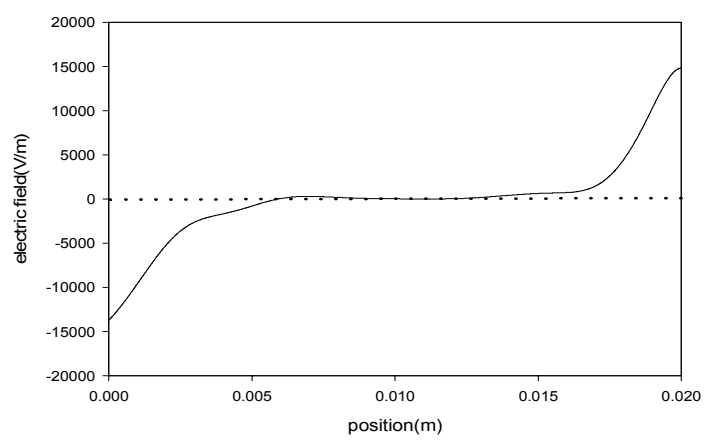

Fig. 7. Spatial variation of electric field.

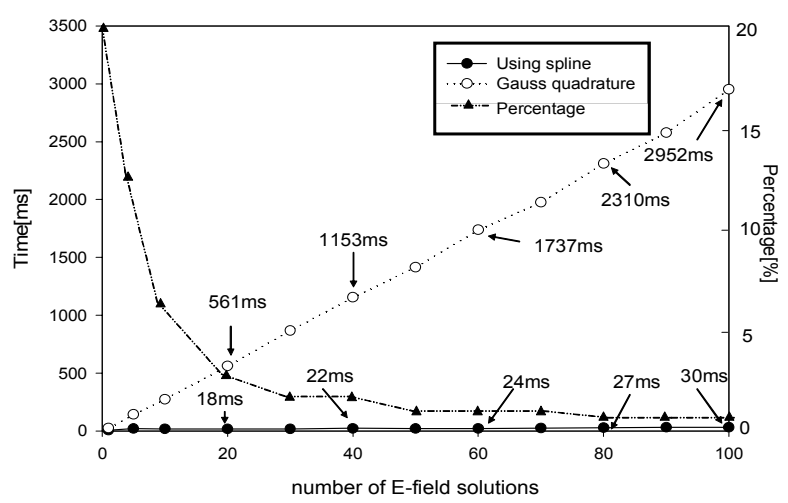

Fig. 8. Calculation time for electric field.

算 1 回のときガウス求積法では $23 \mathrm{~ms}$, 高速電界計算法は $4.7 \mathrm{~ms}$ で比率は $20 \%$ となっており, 1 回の計算においても高 速計算法が早いことがわかる。また，20 回時にガウス求積 法 $561 \mathrm{~ms}$ に対し高速電界計算法は $18 \mathrm{~ms}$ 比率 3\%, 100 回計 算時にはガウス求積法 $2952 \mathrm{~ms}$ に対し高速電界計算法 $30 \mathrm{~ms}$ 比率 $1 \%$ となり, 繰り返し計算するときほど高速電界計算法 が高速であり計算コストを抑えることがわかる。結果から プラズマプロセス MCS のように何度も電界計算を行う場合 に非常に高速であり有効なことがわかる。

\section{5. まとめ}

本論文では, LPWS を一般化した直交展開サンプリングの 精度の評価として，チェビシェフ多項式サンプリングに関 して例を挙げ精度の大きな差異が認められないことを示し た。区間分割して用いられる LPWS では，それを滑らかに 接続するために B-スプライン基底関数をそれぞれの区間の 信頼度として用いていたが，区間の情報としてルジャンド ル展開係数から B-スプライン基底関数の係数を推定し, 分 布関数をスプライン関数表現した。分布関数が B-スプライ ン基底関数の一次結合で表されることとポアソン方程式の 線形性により，あらかじめ B-スプライン基底関数について 電界計算をしておくことで，LPWS から B-スプライン基底 関数の係数が与えられると，それらの重ね合わせより高速 に電界が計算されることを示した。境界の形が曲線を含ま ない形の場合 2 次元, 3 次元に関しても計算できることを示 唆した。本研究を進めるにあたり貴重なご助言を下さった
Tokyo Electron 社 P. L. G.Ventzek 博士に感謝を申し上げます。 (平成 18 年 6 月 27 日受付，平成 19 年 2 月 14 日再受付)

\section{文献}

(1) R. Hatakeyama and T. Kato : "Aligned Carbon Nanotube Formation via Radio-Frequency Magnetron Plasma Chemical Vapor Deposition”, J. Plasma Fusion Res., Vol.81, No.9, pp.653-659 (2005-9) (in Japanese) 畠山力三・加藤俊顕：「磁場中 RF プラズマ CVD によるカーボンナ ノチューブ配向成長」, プラズマ・核融合学誌， 81，9，pp.653-695 (2005-9)

(2) H. Fujiyama : "Inside Coating of Narrow Tubes Using Microplasmas", $J$. Plasma Fusion Res., Vol.76, No.5 pp.465-470 (2000-5) (in Japanese) 藤山 寛：「マイクロプラズマによる細管内面コーティング」，プ ラズマ・核融合学誌, 76, 5, pp.465-470 (2000-5)

(3) I. Horie, T. Suzuki, Y. Ohmori, K. Kitamori, and K. Maruyama : IEEJ Trans. FM, Vol.123, No.9, pp.869-877 (2003-9) (in Japanese) 堀江育也 - 鈴木卓真 - 大森義行 - 北守一隆・ 丸山晃市：「LPWS 法 を用いた $\mathrm{Ar} \mathrm{RF}$ 平行平板プラズマのモンテカルロシミュレーショ ン」, 電学論 A, 123, 9, pp.869-877 (2003-9)

(4) P. L. G. Ventzek and K. Kitamori : "Higher-order sampling strategies in Monte Carlo simulations of electron energy distribution functions in plasmas", J. Appl. Phys., Vol.75, pp.3785-3788 (1994)

(5) K. Satoh, T. Honma, H. Itoh, and H. Tagashira : T. IEE Japan, Vol.120-A, No.2, pp.147-152 (2000-2) (in Japanese)

佐藤孝紀・本間高弘・伊藤秀範・田頭博昭：「ルジャンドル多項式 およびB-spline関数を用いた電子エネルギー分布関数の Higher Order Sampling」, 電学論 A, 120, 2, pp.147-153 (2000-2)

(6) M. Kozaki, K. Satoh, H. Date, H. Itoh, and H. Tagashira : T. IEE Japan, Vol.122-A, No.2, pp.145-150 (2002-2) (in Japanese) 小崎元嗣・佐藤孝紀・伊達広行・伊藤秀範・田頭博昭：「高次のサ ンプリング技法を用いた効果的 PIC/MC simulator の開発」, 電学論 A, 122, 2, pp.145-150 (2002-2)

（7）古川哲也・宮崎洋平・北守一隆：「モンテカルロシミュレーション における直交展開サンプリング」, 情報処理学会第 68 回全国大会講 演論文集, pp.1-81-1-82 (2006-3)

(8) M. Wajima : "On a problem of Riemann integral", Memoirs of the Hokkaido Institute of Technology, No.32, pp.13-14 (2004)

(9) I. Horie, T. Suzuki, K. Kitamori, and K. Maruyama : "Spatio temporal Variation of the Density Distributions in Ar RF Plasmas Using the Monte Carlo Simulation/Legendre Polynomial Weighted Sampling Method", $J$. Appl. Phys., Vol.42, pp.1445-1451 (2003)

宮 崎 洋 平 (学生員) 1979 年 9 月 22 日生。 2002 年 3 月北

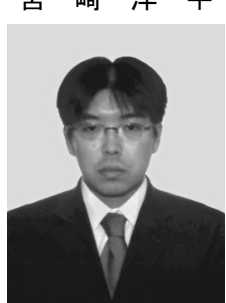
海道工業大学工学部経営工学科卒業。2004 年同 大学院工学研究科機械システム工学専攻修士 課程修了。同年同大学工学研究科機械システム 工学専攻博士課程入学。現在に至る。応用物理 学会会員。

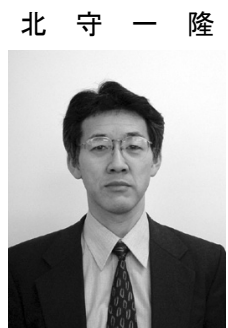

（正員） 1951 年 10 月 7 日生。1975 年北海道 大学電気工学科卒業。1977 年北海道大学大学院 工学研究科修士課程電気工学専攻修了。1980 年北海道大学大学院工学研究科博士課程電気 工学専攻修了。1981 年 4 月北海道電波専門学校 非常勤講師。1982 年北海道工業大学工学部経営 工学科講師。1984 年同大学助教授。1995 年 4 月同大学教授。現在に至る。この間 1992 年 9 月〜1993 年 10 月イリノイ大学電気・計算機工学科客員教授。気体 放電の基礎過程に関する研究に従事。応用物理学会, 日本物理学会, IEEE (Computer, Nuclear and Plasma) 会員。 